\title{
Anticoccidial drugs of the livestock industry
}

\author{
Sandra Noack ${ }^{1} \cdot$ H. David Chapman ${ }^{2} \cdot$ Paul M. Selzer $^{1}$ (D)
}

Received: 8 February 2019 / Accepted: 29 April 2019 / Published online: 31 May 2019

(C) The Author(s) 2019

\begin{abstract}
Coccidiosis is a parasitic disease of a wide variety of animals caused by coccidian protozoa. The coccidia are responsible for major economic losses of the livestock industry. For example, the annual cost due to coccidiosis to the global poultry industry has been estimated to exceed US\$ 3 billion annually. Currently available drugs for the control of this disease are either polyether ionophorous antibiotics that are derived from fermentation products, or synthetic compounds, produced by chemical synthesis. Unfortunately, no new drugs in either category have been approved for use for decades. Resistance has been documented for all those of the drugs currently employed and therefore the discovery of novel drugs with unique modes of action is imperative if chemotherapy is to remain the principal means to control this disease. This chapter aims to give an overview of the efficacy and mode of action of the current compounds used to control coccidiosis in livestock and provides a brief outlook of research needs for the future.
\end{abstract}

Keywords Coccidiosis $\cdot$ Anticoccidials $\cdot$ Livestock $\cdot$ Ionophores $\cdot$ Chemicals $\cdot$ Mode of action $\cdot$ Resistance

\section{Introduction}

Coccidiosis is an infectious disease of the intestinal tract of wild and domestic animals caused by different protozoa. These include but are not limited to Isospora, Neospora, Cryptosporidium, and Eimeria of the phylum Apicomplexa. Those parasites are widespread, especially where intensive production systems are used to raise livestock. They cause mortality, poor growth, and impaired performance. In addition to mortality and reduced growth, coccidiosis also affects meat yield and quality and increases susceptibility to ancillary infections (Nagi and Mathey 1972). In the chicken, at least seven Eimeria species are recognized that parasitize different regions of the intestine (Shirley et al. 1986); many species are recognized in ruminants. The parasites are transmitted from one host individual to others via the feces which shed the transmission stage of the life cycle (the oocyst) into the

Handling Editor: Julia Walochnik

Paul M. Selzer

paul.selzer@boehringer-ingelheim.com

1 Boehringer Ingelheim Vetmedica GmbH, Ingelheim am Rhein, Germany

2 Department of Poultry Science, University of Arkansas, Fayetteville, AR, USA environment. Infection results from ingestion of sporulated oocysts in the litter. The global poultry industry is considered most affected by coccidiosis as it causes this industry annual losses that have been estimated to exceed US\$ 3 billion per year (Williams 1999; Dalloul and Lillehoj 2006). Poultry production is projected to more than double by the year 2050 (Alexandratos and Bruinsma 2012) and control of coccidiosis will be essential if poultry and livestock meat is to fulfill the increasing need for protein by the growing world population (Kart and Bilgili 2008). Control of the disease by the use of drugs is indispensable if we are to achieve sustainable poultry production. Animal welfare is compromised by coccidial infections, and food safety is an important consideration (Kadykalo et al. 2018).

In addition to control programs based upon chemotherapy or vaccination, satisfactory control of coccidiosis in poultry requires strict attention to hygiene and sanitation, and biosecurity measures that limit human access to poultry facilities (Chapman 2018). Adequate ventilation and leak-free watering systems are important to reduce excessive moisture because wet litter aids sporulation of the infective stage of the life cycle (the oocyst). Nevertheless, despite such measures, eradication has not proved possible and the parasites persist in poultry flocks (Chapman et al. 2016). Preventative treatment may employ pharmaceutical ingredients in medicated food or drinking water, or immunization involving the use of live attenuated or non-attenuated vaccines (Klotz et al. 2005). By these means, it is estimated that most 
broiler chickens produced worldwide receive treatment with drugs or are vaccinated (Chapman et al. 2002). Prophylaxis has been the preferred method for the control of coccidiosis in poultry because treatment once clinical signs become apparent is often too late to prevent the pathological consequences of infection (Chapman 2009).

The concept of coccidiosis prevention in chickens by inclusion of drugs in the feed (prophylaxis) was first described in 1948 and involved the use of sulfaquinoxaline, the first feed additive for poultry (Grumbles et al. 1948; reviewed by Chapman 2009). In the years that followed, many other drugs were introduced, and until the introduction of ionophores in the 1970s, chemoprophylactic control of coccidiosis was based on the use of such synthetic anticoccidials (Ryley and Betts 1973). No new chemicals have been introduced for decades, and resistance has been documented for all the drugs approved for use in chickens (Chapman 1997), although the onset of resistance can be slowed by using rotation programs with different chemicals and/or ionophores (Chapman et al. 2010). Nevertheless, resistance to the available chemicals and ionophores has become widespread (Peek and Landman 2011). Drugs with novel molecular modes of action, and hence unprecedented targets, will be necessary if control of coccidiosis by chemotherapy is to be achievable in the future (Kinnaird et al. 2004; Scribner et al. 2009). Very little effort to discover new drugs has been undertaken in recent years, but this may change with the advent of genomics technology (Chapman et al. 2013). Examples of the successful application of novel drug discovery could be shown for other protozoa that are relevant for the animal health industry, e.g., for the pig parasite Cystoiospora suis (Shrestha et al. 2017a).

In this chapter, we aim to give an overview of the efficacy and mode of action of the current compounds used to control coccidiosis in livestock and provide a brief outlook of research needs for the future. Previous reviews of this subject include those by Chapman (1997) and McDougald (1982).

\section{Drug categories}

Anticoccidial drugs belong to one of two categories (Chapman 1997; Allen and Fetterer 2002):

1. Polyether antibiotics or ionophores, which are produced by the fermentation of Streptomyces spp. or Actinomadura spp. These drugs disrupt ion gradients across the cell membrane of the parasite:

(a) Monovalent ionophores (monensin, narasin, salinomycin)

(b) Monovalent glycosidic ionophores (maduramicin, semduramicin)

(c) Divalent ionophore (lasalocid)
2. Synthetic compounds popularly known as "chemicals", produced by chemical synthesis, often with a specific mode of action:

(a) Inhibition of parasite mitochondrial respiration (decoquinate, clopidol)

(b) Inhibition of the folic acid pathway (sulfonamides)

(c) Competitive inhibition of thiamine uptake (amprolium)

(d) Unknown mode of action (e.g., diclazuril, halofuginone, nicarbazin, robenidine)

Combination products, consisting of either a synthetic compound and ionophore (e.g., nicarbazin/narasin Maxiban ${ }^{\circledR}$, Elanco) or two synthetic compounds (clopidol/ methyl benzoquate - Lerbek ${ }^{\circledR}$, Impextraco NV), are also available. Arsenical drugs such as roxarsone that has some anticoccidial efficacy, arsanilic acid, carbarsone, and combinations thereof have been discontinued in many countries since 2015, based on scientific reports that indicated organic arsenic could transform into inorganic, highly toxic arsenic (Nachman et al. 2013; Huang et al. 2014).

\section{Ionophores}

For many years, ionophores have been the principal choice to control coccidiosis because resistance develops slowly to them and because they do not completely suppress parasite development, thus allowing the development of immunity in the host after first exposure (Chapman 1999a, b; Chapman et al. 2010; Jeffers 1989). They are characterized by multiple tetrahydrofuran rings that are connected in the form of spiroketal moieties (Riddell 2002) and are effective against the asexual and sexual life cycle stages of coccidia, disturbing the normal transport of ions across surface membranes of sporozoites or early trophozoites (Augustine et al. 1992; Smith and Galloway 1983; Smith and Strout 1980; Smith et al. 1981). Ionophores are only used in livestock and are not employed for any purpose in human medicine. They are not active against most foodborne bacteria of poultry, e.g., Escherichia coli, Salmonella spp. and Campylobacter spp., and are not, therefore, included in the WHO list of medically important antimicrobials. Their use is not an issue for public health (Tang et al. 2017; WHO 2017).

These drugs have a rather narrow safety margin (Dowling 1992), and most are incompatible with several therapeutic antibiotics. Among those are tiamulin (Umemura et al. 1984a; Islam et al. 2009), chloramphenicol, erythromycin, oleandromycin (Umemura et al. 1984b; Mazlum et al. 1985; Mazlum and Pradella 1986; Perelman et al. 1986; Broz and Frigg 1987), and certain sulfonamides, leading to intoxication manifested by severe temporary clinical symptoms (Dowling 1992; Schuhmacher et al. 2006). In addition, ionophores are also incompatible with some antioxidants (Laczay 1988; 
Laczay et.al. 1988, 1989; Umemura et al. 1984b; Dowling 1992; Peek and Landman 2011).

Monovalent ionophores can form lipid-soluble complexes with sodium and potassium cations, whereas divalent ionophores can bind calcium and magnesium cations only. Polyether ionophores arrest the development of sporozoites by increasing the concentration of intracellular $\mathrm{Na}^{+}$ions. In addition, they increase the activity of $\mathrm{Na}^{+} / \mathrm{K}^{+} /$ATPase (Wang et al. 2006) and affect merozoites by causing the cell membrane to burst (Mehlhorn et al. 1983). Toxic effects in horse, cattle, dogs, cats, rats, and avian species are thought to be mediated by disrupting ion gradients of cell membranes, leading to mitochondrial damage, and thus depletion of cellular energy. Well-known toxic effects are cardiac toxicity and muscle degeneration, and neuropathy, the latter one being manifested by myelin degeneration and ataxia (Chapman 2018; Kart and Bilgili 2008).

\section{Monovalent ionophores}

Monensin In 1967, the structure of monensic acid (Fig. 1e), a fermentation product of Streptomyces cinnamonensis, was first described and the compound was reported to have a broad-spectrum effect against Eimeria (Agtarap et al. 1967). It forms lipid-soluble complexes with sodium and potassium cations, leading to increased permeability of the membrane for these ions. Monensin is able to transport sodium ions through membranes in both electrogenic and electroneutral manner (Mollenhauer et al. 1990). Horses are particularly susceptible to monensin poisoning (Matsuoka et al. 1996). Accidental deadly poisoning of horses with monensin has been published (Doonan et al. 1989; Bezerra et al. 1999; Bila et al. 2001).

Salinomycin Salinomycin (Fig. 1a) was isolated from Streptomyces albus. It exhibits not only activity against Eimeria of poultry but also against gram-positive bacteria including mycobacteria and some filamentous fungi (Miyazaki et al. 1974). Salinomycin is an ionophore with strict selectivity for alkali ions and a strong preference for potassium, interfering with transmembrane potassium potential and promoting the efflux of $\mathrm{K}^{+}$ions from mitochondria and cytoplasm. Recently, it has been shown to kill human cancer stem cells and to inhibit breast cancer growth and metastasis in mice (Naujokat et al. 2010). Salinomycin is the least toxic of all the ionophores (Oehme and Pickrell 1999).

Narasin Narasin (Fig. 1b) is a polyether antibiotic obtained from Streptomyces aureofaciens (Jeffers et al. 1988). It is a derivative of salinomycin having an additional methyl group, therefore alternatively called (4S)-4-methyl salinomycin. When combining different ionophores with nicarbazin, Challey and Jeffers (1973) found that combinations of nicarbazin and narasin had synergistic activity. A combination product containing both active pharmaceutical ingredients (API) in 1:1 ratio was developed (Maxiban $^{\circledR}$ ). Very high levels of narasin caused death in sows, leg muscle weakness in turkeys, and cardiopulmonary clinical signs in $15 \%$ of the rabbits from Brazilian rabbit farms (Oehme and Pickrell 1999).

\section{Monovalent glycosidic ionophores}

Maduramicin The ionophores maduramicin (also called Yumamycin; Fig. 1c) was first isolated from the bacterium Actinomadura yumaensis (Liu et al. 1983). It is a large heterocyclic compound with a series of electronegative crown ethers able to bind monovalent or divalent metal ions (Maron et al. 2015) and is widely used for commercial broiler production. Maduramicin is the most toxic of all the ionophores for nontarget animals (Oehme and Pickrell 1999) and humans (Sharma et al. 2005). It might cause severe cardiovascular defects (Shlosberg et al. 1997), as it inhibits proliferation and induces apoptosis in myoblasts (Chen et al. 2014).

Semduramicin Semduramicin (Fig. 1d) can be isolated from Actinomadura roserufa (Tynan et al. 1992). It is a highly effective drug against Eimeria and is well tolerated by chickens (Ricketts et al. 1992; Logan 1993).

\section{Divalent ionophores}

Lasalocid Compound X-537A (later named lasalocid A; Fig. 1f) was isolated from Streptomyces lasaliensis. It was shown to have anticoccidial activity in chicken (Mitrovic and Schildknecht 1974) and to increase weight gain and feed conversion (Reid 1975).

With the exception of salinomycin, lasalocid is the one with lowest toxicity (Oehme and Pickrell 1999). Nevertheless, dogs appear to be more sensitive to lasalocid intoxication than other species, and accidental poisoning of dogs by lasalocid has been reported (Espino et al. 2003; Segev et al. 2004).

\section{Synthetic compounds}

Based on chemical structure, synthetic drugs include the quinolones, pyridones, alkaloids, guanidines, thiamine analogues, and triazine derivatives (Fig. 2). The mode of action of some synthetic anticoccidials has been described (Wang 1978, 1982) but for others their mode of action needs to be investigated (e.g., diclazuril, halofuginone, nicarbazin, robenidine). Such information and its relevance to the inhibition of specific developmental stages of the life cycle of the parasites are important in understanding toxicity and adverse effects of synthetic anticoccidials, and to obtain optimal control by correct timing of prophylaxis. Structures of synthetic anticoccidials are shown in Fig. 2. 
<smiles>CCC(C(=O)O)[C@H]1CC[C@@H](C)[C@H](C(C)C(O)C(C)C(=O)C(CC)[C@H](O)C(C)C)O1</smiles>

a Salinomycin<smiles>C[C@H]1CC[C@@H](O)[C@]12C=C[C@H](O)[C@]1(CC[C@@H](C)O1)O2</smiles><smiles>CC[C@]1(O)CCC[C@H](C)[C@@H]1C</smiles>

b Narasin

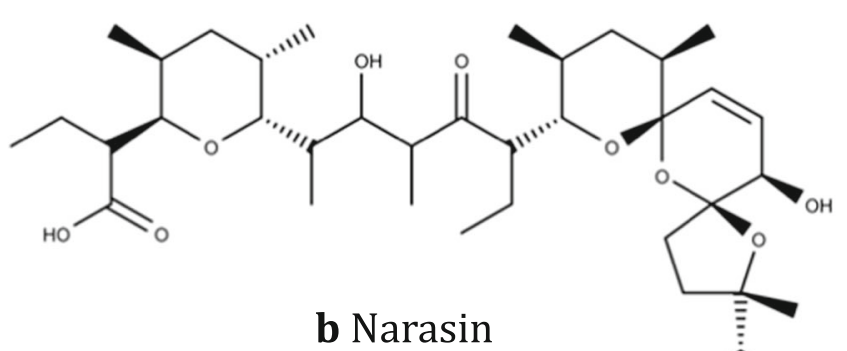

d Semduramycin<smiles>C[C@@H](O)[C@@H](C)C(O)(O)CC(=O)O</smiles><smiles>CO[C@H]1[C@H](C)[C@@](O)(CC=O)O[C@H](C(C)[C@H]2O[C@]3(CCC(C)(C)O3)C[C@H](O)[C@@H]2C)[C@@H]1OC</smiles><smiles>CO[C@H]1C[C@H](C[C@@H]2C[C@H]([C@H]3O[C@](C)(O)[C@@H](C)C[C@H]3C)O[C@H]2[C@]2(C)CCCO2)O[C@@H](C)[C@@H]1OC</smiles><smiles>CO[C@H](C)[C@H](OC)[C@H](C)[C@H]1O[C@@]2(CCC(C)(C)O2)C[C@H](O)[C@@H]1C</smiles><smiles>CC[C@]1([C@H]2O[C@@H]([C@H]3O[C@](O)(CO)[C@H](C)C[C@H]3C)C[C@@H]2C)CC[C@H]([C@]2(C)CC[C@]3(C[C@H](O)[C@@H](C)CO3)O2)O1</smiles>
III...<smiles>C1CCCC1</smiles>

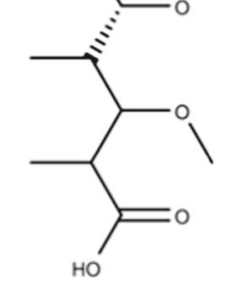

e Monensin

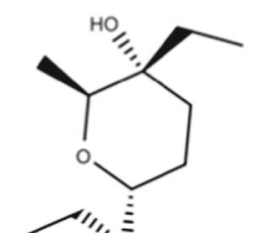

\section{f Lasalocid}<smiles>CC[C@H]1O[C@@](C)(CC)C[C@H]1C</smiles><smiles>CC[C@H](C)C(=O)C(C)C(O)C(C)CCc1ccc(C)c(O)c1C(=O)O</smiles>

Fig. 1 Ionophores used as anticoccidials. While salinomycin, narasin, maduramicin, semduramicin, and monensin (a-e) belong to the monovalent ionophores, lasalocid (f) is a divalent ionphore 
<smiles>CCCCCCCCCCOc1cc2c(=O)c(C(=O)OCC)c[nH]c2cc1OCC</smiles><smiles>CCCCc1cc2c(=O)c(C(=O)OC)c[nH]c2cc1OCc1ccccc1</smiles><smiles>C=CC(Oc1ccc(SC(F)(F)F)cc1)=C(C)C</smiles><smiles>Cc1cc(Cl)c(C(C#N)c2ccc(Cl)cc2)c(Cl)c1</smiles><smiles></smiles><smiles></smiles><smiles>Cc1[nH]c(C)c(Cl)c(=O)c1Cl</smiles>

Clopidol<smiles>NC(N)=N/N=C/c1ccc(Cl)cc1</smiles><smiles>Cc1cc(C)[nH]c(=O)n1</smiles><smiles>CCCc1ncc(C[n+]2ccccc2C)c(N)n1</smiles>

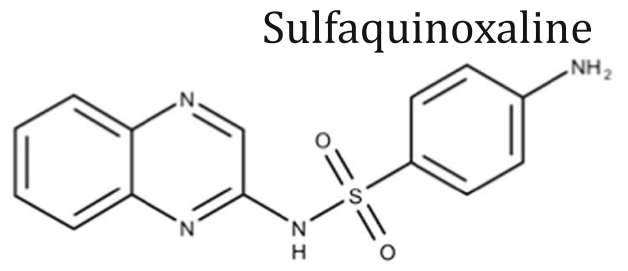

Fig. 2 Synthetic anticoccidial APIs

\section{Inhibition of parasite mitochondrial respiration}

One of the main targets for anticoccidial drugs is the respiratory chain, which is different from vertebrates as Eimeria tenella oocysts predominantly use succinate or malate plus pyruvate to consume oxygen (Wang 1978). As the respiratory chain of protozoa is relatively insensitive to rotenone and amytal, it can be assumed that NADH dehydrogenase is less important than 
succinate dehydrogenase (Harder and Haberkorn 1989). Clopidol and quinolones inhibit mitochondrial energy production during the early stages of Eimeria development, but act on different strains of the coccidia (Anon 2010; Fry and Williams 1984).

Quinolones (decoquinate, nequinate (methyl benzoquate)) Quinolones were first discovered in 1962 and since then have undergone numerous modifications to their nucleus to improve spectrum as well as pharmacokinetics (Galarini et al. 2009). They arrest or kill sporozoites or early trophozoites, but even though they cover a broad spectrum, they are not able to fully control coccidiosis. Quinolone coccidiostats inhibit the respiration by blocking electron transport in the parasite mitochondrion reversibly, probably acting at a site near cytochrome b (Wang 1975, 1976).

Methyl benzoquate, an alkoxy-quinolone ester, acts synergistically with clopidol, a pyridone derivative to prevent Eimeria infections in chicken (Ryley 1975). Decoquinate (6ethyl-(decycloxy)-7-ethoxy-4-hydroxy-3-quinolinecarboxylate) has been introduced in 1967 (Williams 2006). It also shows synergistic effects when combined with clopidol in low concentrations, inhibiting the electron transport more effectively than the sum of their individual actions (Fry and Williams 1984; Wang 1975; Williams 1997). Thus, both APIs are often used in combination products with clopidol. Nevertheless, quinolones and their combination with clopidol are used less frequently today because of the relatively rapid development of resistance (Chapman 1997; Kawazoe et al. 1991).

Clopidol Clopidol, also known as meticlorpindol or clopindol, is a pyridinol with broad coccidiostatic activity against early development of Eimeria spp. by inhibiting mitochondrial energy production in sporozoites and trophozoites (Kant et al. 2013). A synergistic effect between meticlorpindol and 4-hydroxyquinolones has been described (Challey and Jeffers 1973; Jeffers and Challey 1973). To achieve complete control, combination products with quinolones are marketed.

Toltrazuril Toltrazuril interacts with the mitochondrial pyrimidine biosynthesis linked to the respiratory chain; thus, it presumably inhibits mitochondrial dihydroorotate dehydrogenase (Harder and Haberkorn 1989; Jockel et al. 1998). In addition, toltrazuril might affect plastid-like organelles (Hackstein et al. 1995).

Toltrazuril is one of the triazines that acts on intracellular stages of the life cycle that are undergoing schizogony and gamogony (Haberkorn and Stoltefuss 1987), especially affecting mitochondria and the endoplasmatic reticulum (Mehlhorn et al. 1984). Respiratory chain enzymes like succinate-cytochrome $\mathrm{C}$ reductase, NADH oxidase and fumarate reductase as well as enzymes involved in pyrimidine synthesis are inhibited by toltrazuril. However, if one considers the high concentrations needed for inhibition of the latter enzymes, it is questionable whether this mechanism would translate into an anticoccidial effect (Harder and Haberkorn 1989). In addition, nuclear division in schizonts and microgamonts as well as the wall-forming bodies in macrogamonts are disturbed (Mehlhorn et al. 1984).

\section{Inhibition of the folic acid pathway}

The folic acid antagonists include sulfonamides, 2,4diaminopyrimidines, and ethopabate, which are structural analogues of folic acid or of para-aminobenzoic acid (PABA), a precursor of folic acid. They interfere with the synthesis of folic acid by competing with PABA, thereby inhibiting folate synthetase, and thus preventing cellular replication (Lebkowska-Wieruszewska and Kowalski 2010). Diaveridine and ormetoprim are active against the protozoan enzyme dihydrofolate reductase (Lindsay et al. 1996). As coccidia rapidly synthesize nucleic acids, they have high requirements of folic acid - in contrast to their hosts, which are able to utilize folic acid from feed and thus, have no need for PABA (Zaionts et al. 1978).

Sulfonamides Sulfonamides (sulfadimethoxine, sulfaquinoxaline) inhibit dihydropteroate synthetase (McCullough and Maren 1974). They have broad-spectrum activity against Gram-negative and Gram-positive bacteria as well as protozoa. Accidental human consumption of sulfonamidecontaminated products can cause central nervous system effects, gastrointestinal disturbances, and hypersensitivity reactions (Lebkowska-Wieruszewska and Kowalski 2010). Sulfonamides act on developing schizonts and on sexual stages.

Sulfonamides are only used very rarely in US broiler production because of the high potential for residues. On rare occasions only, a combination of sulfadimethoxine and ormetoprim is used in a "prestarter feed" for birds under 16 weeks of age to prevent mortality from coccidiosis and bacterial infections with a 5-day meat withdrawal period (United States Food and Drug Administration, FDA 2016). In Europe, sulfonamides are not approved for prevention of coccidiosis in poultry.

Ethopabate Ethopabate is an antagonist of folic acid or of its precursor, PABA, thus inhibiting the synthesis of nucleic acid and limiting the production of new cells (Anon 2010). It is most active against Eimeria maxima and Eimeria brunetti (Peek and Landman 2011). As it lacks activity against E. tenella caecal stages, it is often used in combination products with amprolium. 


\section{Competitive inhibition of thiamine uptake}

Amprolium Amprolium hydrochloride (1-[(4-amino-2-propyl-5-pyrimidinyl)methyl]-2-methylpyridinium chloride monohydrochloride) is an analogue to thiamine (vitamin $\mathrm{B}_{1}$ ), but lacks the hydroxyethyl functionality that thiamine possesses and thus is not phosphorylated to a pyrophosphate analogue (Kart and Bilgili 2008). It inhibits the uptake of thiamine by second generation schizonts of E. tenella and prevents formation of thiamine pyrophosphate which is required for many essential metabolic reactions, e.g., as cofactor of several decarboxylase enzymes involved in cofactor synthesis (James 1980).

As amprolium is only poorly active against some Eimeria spp., it is largely used in combination products or mixtures with the folic acid antagonists ethopabate or sulfaquinoxaline to extend its spectrum of activity. The primary use of amprolium today is for water treatment during clinical outbreaks. Amprolium is the only active pharmaceutical ingredient approved for prevention and treatment in laying chicken. It has a large safety window (at least 5:1 when used at the recommended level in feed (125 ppm)) (Rychen et al. 2018).

\section{Other modes of action}

Nicarbazin Nicarbazin is an equal molar complex of 4,4'dinitrocarbanalide and 2-hydroxy-4,6-dimethylpyrimidine (Chapman 1994a). It was the first anticoccidial drug with a true broad-spectrum activity and has been in common use since 1955 (Anon 2010). The 4,4'-dinitrocarbanilide component of nicarbazin inhibits transglutaminase activity, whereas the 2-hydroxy-4,6-dimethylpyrimidine portion increases transglutaminase activity. In addition, nicarbazin increases lipoprotein lipase activity and acts as a calcium ionophore (Yoder et al. 2006). Nicarbazin and narasin show synergistic activity (Challey and Jeffers 1973) and a combination product of these drugs was developed. Nicarbazin has only a small safety window. As it disrupts the ion- and water equilibrium, medicated birds are at increased risk of heat stress under hot and humid weather conditions (Keshavarz and McDouglad 1981). In addition, it is highly toxic to layers - symptoms include bleaching of brown-shelled eggs, mottling of yolks, reduced hatchability, and decreased egg production (Jones et al. 1990).

Diclazuril Like toltrazuril, diclazuril belongs to the chemical class of triazines, developed together with clazuril by Janssen Pharmaceuticals (Maes et al. 1988). Diclazuril is a nucleoside analogue thought to be involved in nucleic acid synthesis, possibly affecting later phases of coccidia differentiation (Verheyen et al. 1988). It has been shown to affect parasite wall synthesis resulting in the formation of an abnormally thickened, incomplete oocyst wall, and zygote necrosis in both $E$. brunetti and E. maxima (Verheyen et al. 1989). In addition, diclazuril has been shown to cause disruption of transmembrane potential of mitochondria and to induce ultrastructural changes in merozoites (Zhou et al. 2010). Nevertheless, it is not clear if this is the true mode of action or is just a consequence of cell death. Diclazuril was shown to downregulate mRNA expression of the serine/ threonine protein phosphatase type 5 (PP5) significantly by $51.4 \%$ in E. tenella (Zhou et al. 2013). PP5s of many eukaryotic organisms have important regulatory functions in the cell cycle (Dobson et al. 2001; Lindenthal and Klinkert 2002) and are associated with the apoptosis signal-regulated kinase 1 (ASK1) (Kutuzov et al. 2005).

\section{Unknown modes of action}

Halofuginone Halofuginone hydrobromide is a quinazolinone derivative related to the antimalarial drug febrifuginone. It was originally extracted from leafs and roots of the traditional Chinese herbal Cichroa febrifuga plant, which is used traditionally in Chinese medicine to treat malaria (Pines et al. 2000). It is effective against asexual stages of most species of Eimeria, delaying development (Zhang et al. 2012).

Robenidine Robenidine (1-3-bis (p-chlorobenzylideneamino)guanidine hydrochloride) is a synthetic derivative of guanidine introduced in 1972 (Kennett et al. 1974), which does not affect initial intracellular development of coccidian, but prevents formation of mature schizonts. Its MoA is presumed to interfere with energy metabolism by inhibition of respiratory chain phosphorylation and ATPases, and to inhibit oxidative phosphorylation (Wong et al. 1972; Kant et al. 2013).

\section{Markets and market products}

About 59 billion broilers, 5.8 billion layers, and 1400 billion eggs are produced each year worldwide. The global anticoccidial poultry market as estimated by the animal health industry is approx. US\$ 1 billion (based on Boehringer Ingelheim internal analysis 2016). Academic estimates calculate that the global loss due to coccidiosis in poultry is in excess of US\$ 3 billion (Williams 1999; Shirley et al. 2007). Specifying a value of the market and the cost of coccidiosis in poultry is not an easy if not an impossible task because small errors in such calculations can cause huge differences and there are many different estimates and continuously changing factors involved (e.g., currencies, inflation, energy cost) (Williams 1999). Nevertheless, it is reasonable to speculate how much of these costs can be exploited commercially. If only half of the estimates, it would still be in the range of US\$ 0.5 billion and therefore deserving of further research. To illustrate distinctions in differently regulated markets, we will focus in the next sections on marketed products in Europe, the USA, and Australia (Fig. 3). 
Fig. 3 The global anticoccidial poultry market. a

Endoparasiticides make up 85\% of the total global anticoccidial poultry market; $\mathbf{b}$ the North American and European poultry market are currently the most relevant ones (Boehringer Ingelheim internal analysis 2016)

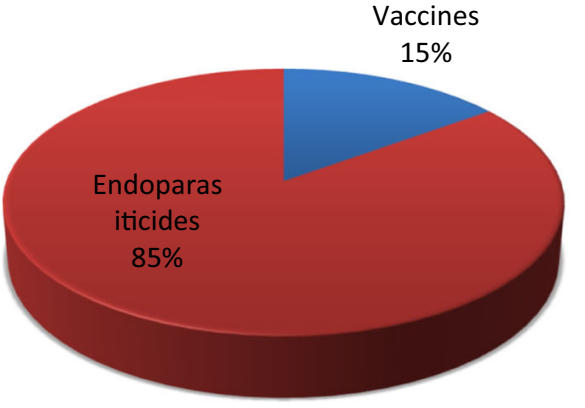

a Percentage of market shares for vaccines and endoparasiticides

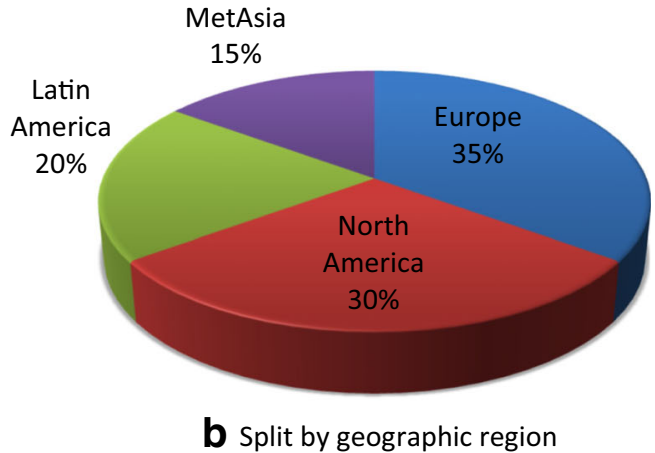

\section{European Union}

In the EU, chemicals are rarely used apart from the synthetic/ ionophore combination product Maxiban ${ }^{\circledR}$. In contrast, in the USA synthetic anticoccidials are often employed in rotational programs with ionophores. Nevertheless, they represent a minor part of the coccidiosis control program. Ionophores are most widely used in the EU, also due to their antibiotic affects in the intestine, e.g., against dysbacteriosis caused by clostridia. The ionophores salinomycin, narasin, monensin, lasalocid, maduramicin, and semduramicin and the chemical anticoccidial drugs robenidine, decoquinate, halofuginone, nicarbazin, and diclazuril are licensed in the EU as zootechnical feed additives under regulation 1831/2003/EC in species where coccidiosis is systematic for biological and zootechnical reasons, which is the case for poultry and rabbits. Systematic means that in these species, diagnosis of coccidiosis is not required and therefore, no prescription is necessary. By contrast, in species where coccidiosis is not systematic, anticoccidials are registered as veterinary medicines (e.g., for cattle; regulated in the European Union by Directive 2001/82/EC). In the UK, more than $40 \%$ of all antimicrobials sold for use in food and non-food animals are employed for the control of coccidia (277 tons of active ingredient in 2011; mostly for control of Eimeria) with ionophores representing more than $70 \%$ of these (Veterinary Medicines Directorate 2012) (Table 1).

\section{USA}

Rotation programs including ionophores and synthetic anticoccidials are the standard in intensive broiler production in the USA. These programs sometimes are also combined with vaccination. In contrast to the $\mathrm{EU}$, the use of antibacterials for growth promotion is allowed in the USA. However, with the Guidance for Industry (GFI) 209 and GFI 213 (FDA 2013), the FDA has enhanced control of use of medically important antibacterials, eliminating the use of them for growth promotion. In addition, in 2017, the USA restricted
Table 1 Anticoccidial products and APIs approved in Europe for use in poultry (data retrieved from European Food Safety Authority http://www.efsa.europa.eu/, Department for Environment, Food \& Rural Affairs https:// www.vmd.defra.gov.uk/ ProductInformationDatabase)

\begin{tabular}{lll}
\hline Anticoccidial API & Trade name & Company \\
\hline Decoquinate & Deccox & Alpharma BVBA; Zoetis SA \\
Diclazuril & Clinacox & Eli Lilly and Company Ltd; Janssen Pharmaceutica NV \\
& Coxiril & Huvepharma NV \\
Halofuginone & Stenorol & Huvepharma NV \\
Lasalocid A & Avatec & Alpharma BVBA; Zoetis SA \\
Maduramicin & Cygro & Alpharma BVBA; Zoetis SA \\
Monensin & Coxidin & Huvepharma NV \\
& Elancoban & Eli Lilly and Company Ltd \\
Narasin & Monteban & Eli Lilly and Company Ltd \\
Narasin + nicarbazin & Maxiban & Eli Lilly and Company Ltd \\
Nicarbazin & Koffogran (Nicarb) & Phibro Animal Health SA \\
Robenidine & Robenz (Cycostst) & Alpharma BVBA; Zoetis SA \\
Salinomycin & Huvesal, Sacox & Huvepharma EOOD; Huvepharma NV \\
Semduramicin & Salinomax & Alpharma BVBA \\
Toltrazuril & Aviax 5\% & Phibro Animal Health SA \\
\hline
\end{tabular}


the use of medically important antibiotics in feed to Veterinary Feed Directives (VFD) that require veterinary oversight (Castanon 2007; Federal Register 2015). The use of a VFD drug in feed is permitted only under the professional supervision of a licensed veterinarian (https://www.fda.gov/ animalveterinary/developmentapprovalprocess/ucm 455416 . $\mathrm{htm}$ ), while administration in drinking water still requires prescription. This restriction led to the withdrawal of some old anticoccidials, as for all, new VFD registrations were required, especially for combination products (Table 2).

\section{Australia}

All agricultural and veterinary chemical products sold in Australia have to be registered by the Australian Pesticides and Veterinary Medicines Authority (APVMA). The "Guideline for the evaluation of the efficacy and safety of coccidiostats" (https://apvma.gov.au/node/427) has to be followed (Table 3).

\section{Control of coccidiosis in ruminants and swine}

As with poultry, Eimeria infections in ruminants are ubiquitously present in the environment and occur wherever animals are raised, especially in heavily stocked pasture with intensive grazing and crowded conditions such as feedlots (Daugschies and Najdrowski 2005; Keeton and Navarre 2018; Taylor and Catchpole 1994). In a study on first-year grazing cattle in Germany, up to $90 \%$ of all animals showed Eimeria-positive fecal samples (von Samson-Himmelstjerna et al. 2006). Probing the scientific literature, it seems that only little research in ruminants has been undertaken (or at least published) for many years, and only a few drugs are currently approved for use. Many of the difficulties in the interpretation of drug efficacy have been described (Gregory et al. 1982). For example, a decrease in oocyst production may follow treatment but this may not be associated with better weight gain and clinical condition. Many field studies show the effects of drugs upon oocyst production but effects upon clinical criteria require artificial inoculation of very large numbers of oocysts. To provide a framework for evaluation of efficacy of anticoccidials in mammals, a respective WAAVP guideline has been published recently (Joachim et al. 2018). This guideline proposes how to conduct both experimental and field studies for dose determination, dose confirmation, and assessment of field effectiveness to obtain solid efficacy data. In addition, guidance on selection of animals, diagnostic techniques, statistical evaluation, and methods concerning preparation, maintenance, and application of parasites is provided.
There are several anticoccidial drugs available for treatment and prevention of coccidiosis in ruminants, both from the class of synthetic drugs (e.g., sulfonamides, amprolium, decoquinate, the triazines diclazuril and toltrazuril) and ionophores (monensin, lasalocid). These drugs are used either therapeutically for the treatment of young animals showing signs of infection (e.g., amprolium, sulfonamides; triazines) or for prevention by inclusion in the feed (e.g., decoquinate, monensin, lasalocid). As most of the damage to the intestine is already present before diagnosis of coccidiosis occurs, therapy is mostly not sufficient to cure, but rather useful to hinder further spread of disease. Therapy has to be combined with palliative application of electrolytes, glucose, and anti-diarrheals to help to maintain hemostasis (Daugschies and Najdrowski 2005).

Only three APIs are currently used for treatment of porcine coccidiosis: narasin, salinomycin, and toltrazuril. Resistance against toltrazuril has been observed not only for Eimeria isolates from chicken (Stephan et al. 1997) and ovine Eimeria field isolates (Odden et al. 2018), but also in a field isolate of Cystoisospora suis, the usual cause of coccidiosis in very young pigs (Shrestha et al. 2017b).

\section{Ionophores}

The divalent ionophore lasalocid has been shown to decrease oocyst production in naturally infected lambs and cattle and in a few cases improve performance and reduce clinical signs of disease when included in the feed (Foreyt et al. 1986; Horton and Stockdale 1981). The efficacy of the monovalent ionophore monensin, employed as a preventive drug by incorporation in the feed of livestock, is well documented (e.g., Bergstrom and Maki 1976; Fitzgerald and Mansfield 1978; Gregory et al. 1983; Leek et al. 1976; McDougald 1978).

\section{Amprolium}

Amprolium has been used for many years for the control coccidiosis in sheep and cattle. The drug is principally used for the treatment of animals showing clinical signs of disease but may be employed for prevention by inclusion in the feed. It is available as an oral solution, soluble powder, or as a pelleted feed additive. The drug was shown to reduce oocyst production in lambs when given as an in-feed medication and an outbreak of clinical coccidiosis was successfully controlled by single drenching followed by medication (Talmon et al. 1989). Amprolium was effective for the control of coccidiosis in feedlot lambs (Baker et al. 1972) and in cattle (Norcross et al. 1974). 
Table 2 Anticoccidial products and APIs approved by the FDA for use in poultry (data retrieved from U.S. Food \& Drug Administration https://www. fda.gov/AnimalVeterinary/default.htm)

\begin{tabular}{|c|c|c|c|c|}
\hline Anticoccidial API & $\begin{array}{l}\text { first } \\
\text { approved }\end{array}$ & Trade names & Company & Combination products available with \\
\hline Amprolium & 1960 & $\begin{array}{l}\text { Amprol; Corid; Amprolium-P } \\
\text { AmproMed P } \\
\text { Cocciprol }\end{array}$ & $\begin{array}{l}\text { Huvepharma EOOD } \\
\text { Cross Vetpharm Group Ltd. } \\
\text { Phibro Animal Health Corp. }\end{array}$ & $\begin{array}{l}\text { Bacitracin, } \\
\text { Bambermycins, } \\
\text { Virginiamycin }\end{array}$ \\
\hline Clopidol & 1968 & Coyden 25 & Huvepharma EOOD & $\begin{array}{l}\text { Bacitracin, Bambermycins, } \\
\text { Chlortetracycline }\end{array}$ \\
\hline Decoquinate & 1970 & Deccox & Zoetis Inc. & $\begin{array}{l}\text { Bacitracin, Chlortetracycline, } \\
\text { Lincomycin }\end{array}$ \\
\hline Diclazuril & 1999 & Clinacox & Huvepharma EOOD & $\begin{array}{l}\text { Bacitracin, Bambermycins, } \\
\text { Virginiamycin }\end{array}$ \\
\hline Halofuginone & 1987 & Stenorol & Huvepharma EOOD & Bacitracin, Bambermycins \\
\hline Lasalocid & 1976 & Avatec & Zoetis Inc. & $\begin{array}{l}\text { Bacitracin, Bambermycins, } \\
\text { Virginiamycin }\end{array}$ \\
\hline Maduramicin & 1989 & Cygro & Zoetis Inc. & - \\
\hline Monensin & 1971 & Coban 90 Coban 60 & Elanco US Inc. & $\begin{array}{l}\text { Avilamycin, Bacitracin, } \\
\text { Bambermycins, Chlortetracycline, } \\
\text { Lincomycin, Ractopamine, } \\
\text { Oxytetracycline, Virginiamycin, } \\
\text { Tilmicosin }\end{array}$ \\
\hline Narasin & 1988 & Monteban 45 & Elanco US Inc. & $\begin{array}{l}\text { Avilamycin, Bacitracin, } \\
\text { Bambermycins }\end{array}$ \\
\hline Nicarbazin & 1955 & $\begin{array}{l}\text { Nicarb } 25 \% \\
\text { Nicarbazin; Carbigran } 25 \\
\text { Nicarmix } 25\end{array}$ & $\begin{array}{l}\text { Phibro Animal Health Corp. } \\
\text { Elanco US Inc. } \\
\text { Planalquimica Industrial } \\
\text { Ltda. }\end{array}$ & Bacitracin, Bambermycins \\
\hline Robenidine & 1972 & Robenz & Zoetis Inc. & $\begin{array}{l}\text { Bacitracin, Chlortetracycline, } \\
\text { Lincomycin, Oxytetracycline }\end{array}$ \\
\hline Salinomycin & 1983 & $\begin{array}{l}\text { Bio-Cox Type A Medicated Article } \\
\text { Sacox } 60\end{array}$ & Huvepharma EOOD & $\begin{array}{l}\text { Avilamycin, Bacitracin, } \\
\text { Bambermycins, Chlortetracycline, } \\
\text { Lincomycin, Oxytetracycline, } \\
\text { Virginiamycin }\end{array}$ \\
\hline Semduramicin & 1995 & Aviax & Phibro Animal Health Corp. & Bacitracin, Virginiamycin \\
\hline Sulfachloropyrazine & & ESB 3 & Zoetis Inc. & - \\
\hline Sulfamethazine & 1945 & $\begin{array}{l}\text { SMZ-Med } 454 \\
\text { Sulmet Soluble Powder }\end{array}$ & $\begin{array}{l}\text { Cross Vetpharm Group Ltd. } \\
\text { Huvepharma EOOD }\end{array}$ & - \\
\hline Sulfadimethoxine & & $\begin{array}{l}\text { ALBON; AGRIBON } \\
\text { SDM Sulfadimethoxine } \\
\quad \text { Concentrated Solution } 12.5 \% \\
\text { Sulfadimethoxine Soluble Powder } \\
\text { Sulfamed-G } \\
\text { Sulfasol Soluble Powder; Sulforal } \\
\text { DI-METHOX; Sulfadimethoxine } \\
\text { 12.5\% Oral Solution; Sulmet } \\
\text { Drinking Water Solution, } 12.5 \%\end{array}$ & $\begin{array}{l}\text { Zoetis Inc. } \\
\text { Cronus Pharma LLC } \\
\text { Phibro Animal Health Corp. } \\
\text { Cross Vetpharm Group Ltd. } \\
\text { Med-Pharmex, Inc. } \\
\text { Huvepharma EOOD }\end{array}$ & - \\
\hline Sulfaquinoxaline & 1948 & $\begin{array}{l}\text { 20\% Sulfaquinoxaline Sodium } \\
\text { Solution; 25\% S.Q. Soluble; S.Q. } \\
\text { 40\%; Sul-Q-Nox } \\
\text { Sulquin 6-50 Concentrate }\end{array}$ & $\begin{array}{l}\text { Huvepharma EOOD } \\
\text { Zoetis Inc. }\end{array}$ & - \\
\hline Zoalene & 1960 & $\begin{array}{l}\text { Zoalene } 90 \text { Medicated Coccidiostat } \\
\text { Zoamix Type A Medicated Article }\end{array}$ & Zoetis Inc. & $\begin{array}{l}\text { Bacitracin, Bambermycins, } \\
\text { Lincomycin }\end{array}$ \\
\hline $\begin{array}{c}\text { Amprolium + } \\
\text { ethopabate }\end{array}$ & 1997 & $\begin{array}{l}\text { Amprol Plus } \\
\text { Amprol Hi-E } \\
\text { Amprol Plus 3-Nitro }\end{array}$ & Huvepharma EOOD & $\begin{array}{l}\text { Bacitracin, Bambermycins, } \\
\text { Chlortetracycline }\end{array}$ \\
\hline Narasin + nicarbazin & 1989 & Maxiban 72 & Elanco US Inc. & $\begin{array}{l}\text { Avilamycin, Bacitracin, } \\
\text { Bambermycins }\end{array}$ \\
\hline $\begin{array}{l}\text { Ormetoprim }+ \\
\quad \text { sulfadimethoxine }\end{array}$ & 1970 & Rofenaid 40 & Zoetis Inc. & - \\
\hline $\begin{array}{l}\text { Sulfamethazine }+ \\
\quad \text { sulfaquinoxaline }\end{array}$ & 2006 & PoultrySulfa & Huvepharma EOOD & Sulfamerazine \\
\hline
\end{tabular}


Table 3 Anticoccidial products and APIs approved in Australia for use in poultry (data retrieved from Australian Pesticides and Veterinary Medicines Authority https://apvma.gov.au)

\begin{tabular}{|c|c|c|c|}
\hline Anticoccidial API & First approved & Trade names & Company \\
\hline 3,5-Dinitro-O-toluamide & 1994 & $\begin{array}{l}\text { Dot } \\
\text { Dot premix } \\
\text { Doteco } \\
\text { Nutridot } \\
\text { Phibrodot }\end{array}$ & $\begin{array}{l}\text { Dox-Al Australia PTY Ltd } \\
\text { Bec Feed Solutions PTY Ltd } \\
\text { International Animal Health Products PTY Ltd } \\
\text { Nutriment Health PTY Ltd } \\
\text { Phibro Animal Health PTY Limited }\end{array}$ \\
\hline Amprolium & 1996 & Amprolium & Parafarm PTY Ltd \\
\hline Decoquinate & 2016 & Deccox & Zoetis Australia PTY Ltd \\
\hline Lasalocid & 2001 & Avatec & Zoetis Australia PTY Ltd \\
\hline Maduramicin & 1997 & $\begin{array}{l}\text { CyGro } \\
\text { Maduradox }\end{array}$ & $\begin{array}{l}\text { Zoetis Australia PTY Ltd } \\
\text { Dox-Al Australia PTY Ltd }\end{array}$ \\
\hline Monensin & 1994 & $\begin{array}{l}\text { CCD Monensin, Rumensin } \\
\text { Coxidin } \\
\text { Doxaban } \\
\text { Monendox } \\
\text { Moneco } \\
\text { Neove Monensin } \\
\text { Phibromonensin }\end{array}$ & $\begin{array}{l}\text { Elanco Australasia PTY Ltd } \\
\text { Huvepharma EOOD } \\
\text { Dox-Al Italia S.P.A. } \\
\text { Dox-Al Australia PTY Ltd } \\
\text { International Animal Health Products PTY Ltd } \\
\text { Nutriment Health PTY Ltd } \\
\text { Phibro Animal Health PTY Limited }\end{array}$ \\
\hline Narasin & 1984 & Elanco Narasin, Monteban & Elanco Australasia PTY Ltd \\
\hline Nicarbazin & 1996 & $\begin{array}{l}\text { Carbidox } \\
\text { Cycarb } \\
\text { Elanco Nicarbazin, Carbigran } \\
\text { Keymix } \\
\text { Nutrinicarb } \\
\text { Phicarb }\end{array}$ & $\begin{array}{l}\text { Dox-Al Australia PTY Ltd } \\
\text { Zoetis Australia PTY Ltd } \\
\text { Elanco Australasia PTY Ltd } \\
\text { International Animal Health Products PTY Ltd } \\
\text { Nutriment Health PTY Ltd } \\
\text { Phibro Animal health PTY limited }\end{array}$ \\
\hline Robenidine & 2003 & $\begin{array}{l}\text { Cycostat } \\
\text { Nutrirob }\end{array}$ & $\begin{array}{l}\text { Zoetis Australia PTY Ltd } \\
\text { Nutriment Health PTY Ltd }\end{array}$ \\
\hline Salinomycin & 1996 & $\begin{array}{l}\text { Bio-Cox, Sacox } \\
\text { CCD Salinomycin } \\
\text { Coxistac } \\
\text { Neove } \\
\text { Sadox, Salindox } \\
\text { Doxalino } \\
\text { Saleco }\end{array}$ & $\begin{array}{l}\text { Huvepharma EOOD } \\
\text { CCD Animal Health PTY Ltd } \\
\text { Phibro Animal Health PTY Limited } \\
\text { Nutriment Health PTY Ltd } \\
\text { Dox-Al Australia PTY Ltd } \\
\text { Dox-Al Italia S.P.A } \\
\text { International Animal Health Products PTY Ltd }\end{array}$ \\
\hline Semduramicin & 1998 & Aviax & Phibro Animal health PTY limited \\
\hline Sulfaquinoxaline & 1983 & Inca Sulpha-Quin & Inca (Flight) Co PTY Ltd \\
\hline Toltrazuril & 1993 & $\begin{array}{l}\text { Baycox, Toltracox Poultry } \\
\text { Coxi-Stop }\end{array}$ & $\begin{array}{l}\text { Bayer Australia Ltd. (Animal Health) } \\
\text { Abbey Laboratories PTY Ltd }\end{array}$ \\
\hline Diaveridine + sulfaquinoxaline & 1990 & Keymix Solquin & International Animal Health Products PTY Ltd \\
\hline Amprolium + ethopabate & 1989 & Keymix Keystat & International Animal Health Products PTY Ltd \\
\hline Maduramicin + nicarbazin & 2005 & Gromax & Zoetis Australia PTY Ltd \\
\hline Methyl benzoquate + clopidol & 1993 & Lerbek & Feedworks PTY Ltd \\
\hline
\end{tabular}

\section{Decoquinate}

This drug is used for the prevention of coccidiosis in young ruminants by incorporation in the feed. Its efficacy has been demonstrated in sheep, goats, and cattle (Fitzgerald and Mansfield 1989; Foreyt 1987; Miner and Jensen 1976).

\section{Triazines}

Numerous studies have shown that diclazuril and toltrazuril, when administered orally to young cattle, lambs, or pigs prior to the onset of clinical signs (referred to as metaphylactic treatment), decreases oocyst production in natural and artificial 
infections with Eimeria species (Bohrmann 1991; Mundt et al. 2003a, 2005, 2009; Epe et al. 2005; Daugschies et al. 2007) or Isospora suis (Driesen et al. 1995; Mundt et al. 2003b, 2007; Kreiner et al. 2011). In some cases, improvements in performance have been demonstrated (e.g., Ruiz et al. 2012; Scala et al. 2009; Rypula et al. 2012).

\section{Sulfonamides}

Various sulfonamides, such as sulfaquinoxaline and sulfaguanidine, have been used for many years for the treatment of livestock showing clinical signs of coccidiosis (e.g. Hammond et al. 1956). As appetite is depressed in infected animals then inclusion in the drinking water is preferable for treatment (Shumard 1957).

\section{Registered APIs in different markets}

\section{European Union}

In the European Union, only few anticoccidial APIs are registered for use in ruminants and/or pigs (mostly piglets): decoquinate, diclazuril, lasalocid, monensin, and toltrazuril (European Medicines Agency www.EMA.Europa.eu).

\section{USA}

In the USA, anticoccidials for use in ruminants and pigs are mainly used in combinations as feed additives, combined with antibacterials and growth promoters. Registered APIs are as follows:

\begin{tabular}{llll}
\hline Amprolium & Clopidol & Decoquinate & Dexamethasone \\
Diclazuril & Ethopabate & Halofuginone & Lasalocid \\
Maduramicin & Monensin & Narasin & Nicarbazin \\
Ormetoprim & Robenidine & Salinomycin & Semduramicin \\
Sulfachloropyrazine & Sulfadimethoxine & Sulfamerazine & Sulfamethazine \\
Sulfaquinoxaline & Tylosin & Zoalene & \\
\hline
\end{tabular}

(Source: U.S. Food \& Drug Administration https://www. fda.gov/AnimalVeterinary/default.htm).

\section{Australia}

In Australia, only lasalocid, monensin, narasin, salinomycin, and toltrazuril are registered anticoccidials for treatment of ruminants and/or pigs (Australian Pesticides and Veterinary Medicines Authority https://apvma.gov.au).

\section{Resistance and research for new anticoccidials}

Development of resistance is a threat for all drugs that are used extensively for a prolonged time. A consequence of this is documented resistance for all drugs in intensive poultry production (Table 4) (Chapman 1997). In a survey conducted in the USA from 1995 to 1999 , it was found that anticoccidials were universally used by $99 \%$ of commercial broiler operations (Chapman 2001).

The polyether ionophores became the drug of choice in 1972 and remain the most extensively used drugs in poultry as of today. While the development of resistance to ionophores is rather slow probably due to their unique mode of action, resistance development in synthetic drugs that have a specific mode of action seems to appear more rapidly, involving genetic mechanisms. Sometimes resistance was reported shortly after marketing a new drug, an example being arprinocid (Fig. 4) (Chapman 1983). Another example is the quinolone buquinolate (Fig. 4) that was "commercially dead" within 6 months of its introduction due to the sudden appearance of drug resistance. Development of resistance against buquinolate was found to take place after a single experimental passage of Eimeria (Chapman 1975). By comparison, drug resistance against toltrazuril did not occur in at least five successive drug exposures in field studies (Claeskens et al. 2007).

A study on ten Eimeria field isolates from northern Germany detected resistance against in nine out of the ten isolates of Eimeria, with seven out of the ten having developed multiple resistance (Stephan et al. 1997). Similar results have been shown in isolates from broiler farms in the UK (Chapman 1993) and the Netherlands (Peek and Landman 2006), showing the enormous threat of development of broad resistance against all classes of anticoccidial drugs. As drug sensitivity in a population of coccidia can be altered by the introduction of drug-sensitive coccidia, e.g., through the use of coccidiosis vaccines, or by the use of drug-sensitive laboratory-maintained lines or other reservoirs (Ball 1966; Jeffers 1976; McLoughlin and Chute 1978), these measures have to be combined in an attempt to control coccidiosis. Restoration of sensitivity to drugs following the use of vaccines comprising drug-sensitive strains of Eimeria has been demonstrated for the ionophores, monensin, and salinomycin, and the synthetic drug diclazuril (Chapman 1994b; Chapman and Jeffers 2014, 2015; Jenkins et al. 2010; Peek and Landman 2006; Mathis and Broussard 2006). Partial restoration of sensitivity to diclazuril and monensin was also observed following use of attenuated vaccine (Peek and Landman 2006). Therefore, a yearly rotation program has been proposed in which use of ionophores is alternated in successive flocks with vaccination (Chapman et al. 2010).

The development of resistance led to increasing efforts for the identification of new, resistance-breaking drugs. One recent example is nitromezuril, a new triazine anticoccidial. It shows only limited cross-resistance with diclazuril or toltrazuril (Fei et al. 2013), but these results have to be further evaluated before this drug might finally enter the market. 
Table 4 Summary of reported resistance to anticoccidials in field strains of Eimeria (adapted from Chapman 1997)

\begin{tabular}{|c|c|c|c|c|}
\hline Drug & Year of introduction & Country where resistance was first described & Year resistance was first described & Species $^{\mathrm{a}}$ \\
\hline Sulphaquinoxaline & 1948 & USA & 1954 & Et \\
\hline Nitrofurazone & 1948 & USA & 1955 & Not given \\
\hline Nicarbazin & 1955 & Britain & 1964 & $E t$ \\
\hline Dinitolmide & 1960 & Britain & 1964 & $E t, E n$ \\
\hline Amprolium & 1960 & Britain & 1964 & $E b$ \\
\hline Clopidol & 1966 & Britain & 1969 & $E a, E m, E t$ \\
\hline Buquinolate & 1967 & USA & 1968 & Not given \\
\hline Methyl benzoquate & 1967 & Britain & 1970 & $E t$ \\
\hline Decoquinate & 1967 & Britain & 1970 & $E t$ \\
\hline Monensin & 1971 & USA & 1974 & $E m$ \\
\hline Robenidine & 1972 & USA & 1974 & Em \\
\hline Halofuginone & 1975 & France & 1986 & $E a, E t$ \\
\hline Lasalocid & 1976 & USA & 1977 & $E a$ \\
\hline Arprinocid & 1980 & Britain & 1982 & $E t$ \\
\hline Salinomycin & 1983 & USA & 1984 & Various \\
\hline Diclazuril & 1990 & Brazil & 1994 & $E a, E m, E t$ \\
\hline Toltrazuril & 1986 & Netherlands & 1993 & Not given \\
\hline
\end{tabular}

\section{Conclusion}

In the light of the continuously expanding livestock industry and its growing significance for global food production, control of coccidiosis, perhaps the most widespread and intractable disease of poultry and other livestock, is of great importance; however, relatively little effort has been made on Eimeria infections of domestic livestock (Engels et al. 2010; Fernandez et al. 2012; Marhöfer et al. 2013; Müller and Hemphill 2016). In view of advances in biotechnology, modern approaches towards the discovery of novel resistancebreaking drug candidates may be anticipated. Genomic analysis of all seven Eimeria species that cause coccidiosis in poultry has been accomplished (Reid et al. 2014) and this may allow the identification and validation of species-specific protein targets. Novel drug discovery rationales including high throughput screening, structural biology, and the elucidation of the mode of action of active compounds can be envisioned. Combining target-based approaches with parasite in vitro and in vivo testing and medicinal chemistry generates a comprehensive view on the genotype-to-phenotype-tocompound correlation, which could allow for the design of novel drug candidates. Unfortunately, resistance develops rapidly following the introduction of drugs in the field. The
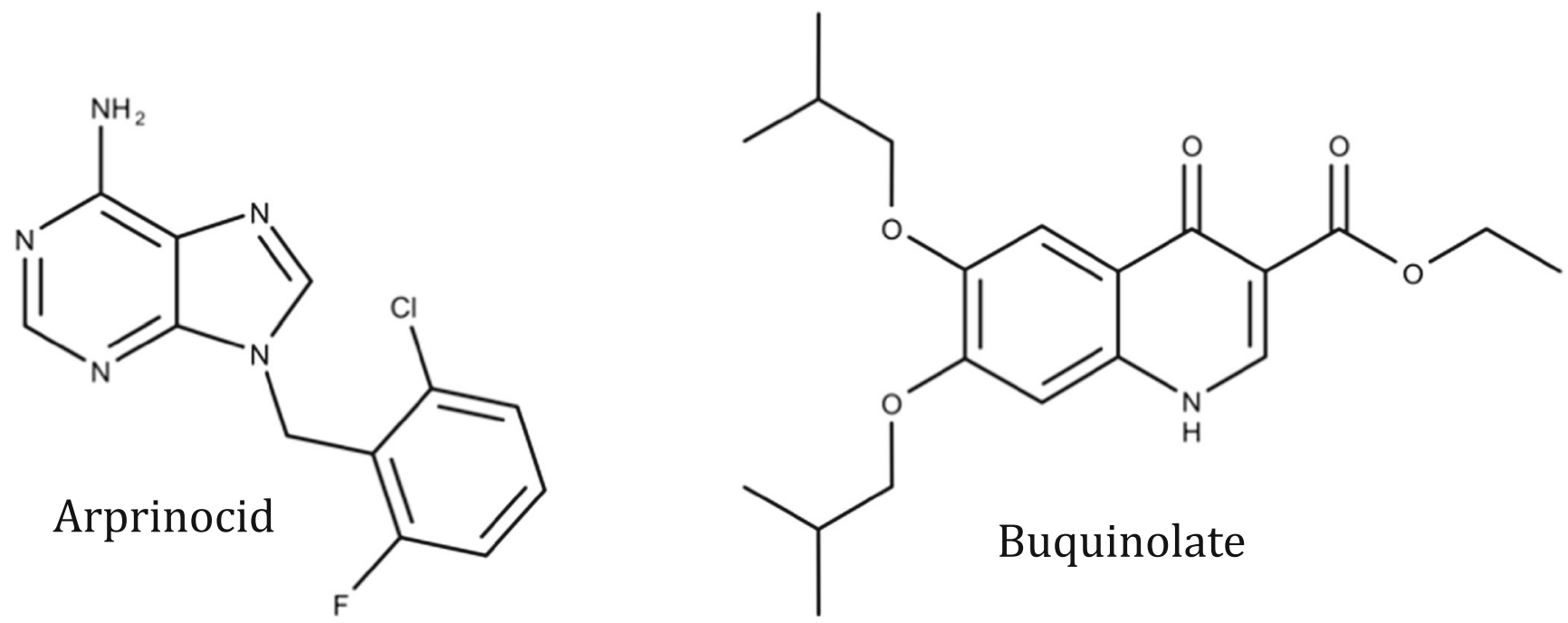

Fig. 4 Chemical structures of arprinocid and buquinolate 
current approach to delay the onset of resistance is to employ rotation programs combined with good husbandry, chemoprophylaxis, and/or live parasite vaccination (Blake et al. 2017). However, for the control of coccidiosis in the future, both novel cost-effective preventative chemotherapy and subunit or recombinant vaccines are desperately needed.

\section{Compliance with ethical standards}

Conflict of interest SN and PS are employees of Boehringer Ingelheim Vetmedica $\mathrm{GmbH}$, an organization with commercial interest in the animal health market. HDC is a member of the University of Arkansas, declaring no competing interests.

Open Access This article is distributed under the terms of the Creative Commons Attribution 4.0 International License (http:// creativecommons.org/licenses/by/4.0/), which permits unrestricted use, distribution, and reproduction in any medium, provided you give appropriate credit to the original author(s) and the source, provide a link to the Creative Commons license, and indicate if changes were made.

\section{References}

Agtarap A, Chamberlin JW, Pinkerton M, Steinrauf L (1967) The structure of monensic acid, a new biologically active compound. J Am Chem Soc 89:5737-5739

Alexandratos N, Bruinsma J (2012) World agriculture towards 2030/2050: the 2012 revision (ESA working paper no. 12-03). FAO. Agricultural Development Economics Division, Global Perspective Studies Team http://www.fao.org/fileadmin/templates/ esa/Global_persepctives/world_ag_2030_50_2012_rev.pdf

Allen PC, Fetterer RH (2002) Recent advances in biology and immunobiology of Eimeria species and in diagnosis and control of infection with these coccidian parasites of poultry. Clin Microbiol Rev 15(1):58-65

Anon (2010) The Merck veterinary manual, Vol. 10. Merck \& Co., Inc, New Jersey

Augustine PC, Watkins KL, Danforth HD (1992) Effect of monensin on ultrastructure and cellular invasion by the turkey coccidia Eimeria adenoeides and Eimeria meleagrimitis. Poult Sci 71(6):970-978. https://doi.org/10.3382/ps.0710970

Baker NF, Walters GT, Fisk RA (1972) Amprolium for control of coccidiosis in feedlot lambs. Am J Vet Res 33(1):83-86

Ball SJ (1966) The development of resistance to glycarbylamide and 2chloro-4-nitrobenzamide in Eimeria tenella in chicks. Parasitology 56:25-37

Bergstrom RC, Maki LR (1976) Coccidiostatic action of monensin fed to lambs: body weight gains and feed conversion efficacy. Am J Vet Res 37(1):79-81

Bezerra PS, Driemeier D, Loretti AP, Riet-Correa F, Kamphues J, de Barros CS (1999) Monensin poisoning in Brazilian horses. Vet Hum Toxicol 41(6):383-385

Bila CG, Perreira CL, Gruys E (2001) Accidental monensin toxicosis in horses in Mozambique. J South African Vet Assoc 72(3):163-164

Blake DP, Pastor-Fernandez I, Nolan MJ, Tomley FM (2017) Recombinant anticoccidial vaccines - a cup half full? Infect Genet Evol 55:358-365. https://doi.org/10.1016/j.meegid.2017.10.009

Bohrmann R (1991) Treatment with toltrazuril in a natural outbreak of coccidiosis in calves. Dtsch Tierarztl Wochenschr 98(9):343-345
Broz J, Frigg M (1987) Incompatibility between lasalocid and chloramphenicol in broiler chicks after a long-term simultaneous administration. Vet Res Commun 11(2):159-172

Castanon JI (2007) History of the use of antibiotic as growth promoters in European poultry feeds. Poult Sci 86(11):2466-2471. https://doi. org/10.3382/ps.2007-00249

Challey JR, Jeffers TK (1973) Synergism between 4-hydroxyquinoline and pyridone coccidiostats. J Parasitol 59(3):502-504

Chapman HD (1975) Eimeria tenella in chickens: development of resistance to quinolone anticoccidial drugs. Parasitology 71:41-49

Chapman HD (1983) Field isolated of Eimeria resistant to arprinocid. Vet Parasitol 12(1):45-50

Chapman HD (1993) Resistance to anticoccidial drugs in fowl. Parasitol Today 9:159-162

Chapman HD (1994a) A review of the biological activity of the anticoccidial drug nicarbazin and its application for the control of coccidiosis in poultry. Poult Sci Rev 5:231-243

Chapman HD (1994b) Sensitivity of field isolates of Eimeria to monensin following the use of a coccidiosis vaccine in broiler chickens. Poult Sci 73:476-478

Chapman HD (1997) Biochemical, genetic and applied aspects of drug resistance in Eimeria parasites of the fowl. Avian Pathol 26:221-244

Chapman HD (1999a) Anticoccidial drugs and their effects upon the development of immunity to Eimeria infections in poultry. Avian Pathol 28:521-535

Chapman HD (1999b) The development of immunity to Eimeria species in broilers given anticoccidial drugs. Avian Pathol 28:155-162

Chapman HD (2001) Use of anticoccidial drugs in broiler chickens in the USA: analysis for the years 1995 to 1999. Poult Sci 80:572-580

Chapman HD (2009) A landmark contribution to poultry scienceprophylactic control of coccidiosis in poultry. Poult Sci 88:813-815

Chapman HD (2018) Applied strategies for the control of coccidiosis in poultry. CAB Rev 13:1-11

Chapman HD, Jeffers TK (2014) Vaccination of chickens against coccidiosis ameliorates drug resistance in commercial poultry production. Int J Parasitol Drugs Drug Resist 4:214-217

Chapman HD, Jeffers TK (2015) Restoration of sensitivity to salinomycin in Eimeria following 5 flocks of broiler chickens reared in floor-pens using drug programs and vaccination to control coccidiosis. Poult Sci 94:943-946

Chapman HD, Cherry TE, Danforth HD, Richards G, Shirley MW, Williams RB (2002) Sustainable coccidiosis control in poultry production: the role of live vaccines. Int J Parasitol 32:617-629

Chapman HD, Jeffers TK, Williams RB (2010) Forty years of monensin for the control of coccidiosis in poultry. Poult Sci 89:1788-1801

Chapman HD, Barta JR, Blake D, Gruber A, Jenkins M, Smith NC, Suo X, Tomley FM (2013) A selective review of advances in coccidiosis research. Adv Parasitol 83:93-171

Chapman HD, Barta JR, Hafeez MA, Matsler P, Rathinam T, Raccoursier M (2016) The epizootiology of Eimeria infections in commercial broiler chickens where anticoccidial drug programs were employed in six successive flocks to control coccidiosis. Poult Sci 95:1774 1778

Chen X, Gu Y, Singh K, Shang C, Barzegar M, Jiang S, Huang S (2014) Maduramicin inhibits proliferation and induces apoptosis in myoblast cells. PLoS One 9(12):e115652. https://doi.org/10.1371/ journal.pone. 0115652

Claeskens M, Verdonck W, Heesen H, Froyman R, Torres A (2007) A field study assessing control of broiler coccidiosis by Paracox ${ }^{\mathrm{TM}}$ vaccination or by Toltrazuril (Baycox $\left.{ }^{\circledR}\right)$ stand-alone treatment. Parasitol Res 101:105-112

Dalloul RA, Lillehoj HS (2006) Poultry coccidiosis: recent advancements in control measures and vaccine development. Expert Rev Vaccines 5(1):143-163. https://doi.org/10.1586/14760584.5.1.143 
Daugschies A, Najdrowski M (2005) Eimeriosis in cattle: current understanding. J Vet Med B Infect Dis Vet Public Health 52(10):417-427. https://doi.org/10.1111/j.1439-0450.2005.00894.x

Daugschies A, Agneessens J, Goossens L, Mengel H, Veys P (2007) The effect of a metaphylactic treatment with diclazuril (Vecoxan) on the oocyst excretion and growth performance of calves exposed to a natural Eimeria infection. Vet Parasitol 149(3-4):199-206. https:// doi.org/10.1016/j.vetpar.2007.08.003

Dobson S, Kar B, Kumar R, Adams B, Barik S (2001) A novel tetratricopeptide repeat (TPR) containing PP5 serine/threonine protein phosphatase in the malaria parasite, Plasmodium falciparum. BMC Microbiol 1:31

Doonan GR, Brown CM, Mullaney TP, Brooks DB, Ulmanis EG, Slanker MR (1989) Monensin poisoning in horses - an international incident. Can Vet J 30(2):165-169

Dowling L (1992) Ionophore toxicity in chickens: a review of pathology and diagnosis. Avian Pathol 21(3):355-368. https://doi.org/10.1080/ 03079459208418854

Driesen SJ, Fahy VA, Carland PG (1995) The use of toltrazuril for the prevention of coccidiosis in piglets before weaning. Aust Vet $\mathbf{J}$ 72(4):139-141

Engels K, Beyer C, Suárez Fernández ML, Bender F, Gassel M, Unden G, Marhöfer RJ, Mottram JC, Selzer PM (2010) Inhibition of Eimeria tenella CDK-related kinase 2: from target identification to lead compounds. Chem Med Chem 5(8):1259-1271. https://doi.org/ 10.1002/cmdc. 201000157

Epe C, von Samson-Himmelstjerna G, Wirtherle N, von der Heyden V, Welz C, Beening J, Radeloff I, Hellmann K, Schnieder T, Krieger K (2005) Efficacy of toltrazuril as a metaphylactic and therapeutic treatment of coccidiosis in first-year grazing calves. Parasitol Res 97:S127-s133. https://doi.org/10.1007/s00436-005-1456-x

Espino L, Suarez ML, Mino N, Goicoa A, Fidalgo LE, Santamarina G (2003) Suspected lasalocid poisoning in three dogs. Vet Hum Toxicol 45(5):241-242

FDA (2013) CVM GFI \#213 New Animal Drugs and New Animal Drug Combination Products Administered in or on Medicated Feed or Drinking Water of Food-Producing Animals: Recommendations for Drug Sponsors for Voluntarily Aligning Product Use Conditions with GFI \#209 http://www.fda.gov/downloads/ AnimalVeterinary/GuidanceComplianceEnforcement/ GuidanceforIndustry/UCM299624.pdf. Accessed 11 Apr 2019

FDA (2016) 21CFR558.575 Sulfadimethoxine and ormetoprim. https:// www.accessdata.fda.gov/scripts/cdrh/cfdocs/cfcfr/CFRSearch.cfm? $\mathrm{fr}=558.575$. Accessed 11 April 2019

Fei C, Fan C, Zhao Q, Lin Y, Wang X, Zheng W, Wang M, Zhang K, Zhang L, Li T, Xue F (2013) Anticoccidial effects of a novel triazine nitromezuril in broiler chickens. Vet Parasitol 198(1-2):39-44

Fernandez ML, Engels KK, Bender F, Gassel M, Marhöfer RJ, Mottram JC, Selzer PM (2012) High-throughput screening with the Eimeria tenella $\mathrm{CDC} 2$-related kinase2/cyclin complex EtCRK2/EtCYC3a. Microbiology 158(Pt 9:2262-2271. https://doi.org/10.1099/mic.0. 059428-0

Fitzgerald PR, Mansfield ME (1978) Ovine coccidiosis: effect of the antibiotic monensin against Eimeria ninakohlyakimovae and other naturally occurring coccidia of sheep. Am J Vet Res 39(1):7-10

Fitzgerald PR, Mansfield ME (1989) Effects of intermittent and continuous administration of decoquinate on bovine coccidiosis in male calves. Am J Vet Res 50(6):961-964

Foreyt WJ (1987) Coccidiosis in sheep and goats. Vet Hum Toxicol 29(Suppl 1):60-64

Foreyt WJ, Rice DH, Wescott RB (1986) Evaluation of lasalocid as a coccidiostat in calves: titration, efficacy, and comparison with monensin and decoquinate. Am J Vet Res 47(9):2031-2035

Fry M, Williams RB (1984) Effects of decoquinate and clopidol on electron transport in mitochondria of Eimeria tenella (Apicomplexa: coccidia). Biochem Pharmacol 33(2):229-240
Galarini R, Fioroni L, Angelucci F, Tovo GR, Cristofani E (2009) Simultaneous determination of eleven quinolones in animal feed by liquid chromatography with fluorescence and ultraviolet absorbance detection. J Chromatogr A 1216(46):8158-8164. https://doi. org/10.1016/j.chroma.2009.06.076

Gregory MW, Joyner LP, Catchpole J (1982) Medication against ovine coccidiosis - a review. Vet Res Commun 5(4):307-325

Gregory MW, Catchpole J, Joyner LP, Parker BN (1983) Observations on the epidemiology of coccidial infections in sheep under varying conditions of intensive husbandry including chemoprophylaxis with monensin. Parasitology 87:421-427

Grumbles LC, Delaplane JP, Higgins TC (1948) Continuous feeding of low concentrations of sulfaquinoxaline for the control of coccidiosis in poultry. Poult Sci 27(5). https://doi.org/10.3382/ps.0270605

Haberkorn A, Stoltefuss J (1987) Studies on the activity spectrum of toltrazuril, a new anticoccidial agent. Vet Med Rev 1:22-32

Hackstein JH, Mackenstedt U, Mehlhorn H, Meijerink JP, Schubert H, Leunissen JA (1995) Parasitic apicomplexans harbor a chlorophyll a-D1 complex, the potential target for therapeutic triazines. Parasitol Res 81(3):207-216

Hammond DM, Shupe JL, Johnson AE, Fitzgerald PR, Thorne JL (1956) Sulfaquinoxaline and sulfamerazine in the treatment of experimental infections with Eimeria bovis in calves. Am J Vet Res 17(64):463470

Harder A, Haberkorn A (1989) Possible mode of action of toltrazuril: studies on two Eimeria species and mammalian and Ascaris suum enzymes. Parasitol Res 76(1):8-12

Horton GM, Stockdale PH (1981) Lasalocid and monensin in finishing diets for early weaned lambs with naturally occurring coccidiosis. Am J Vet Res 42(3):433-436

Huang L, Yao L, He Z, Zhou C, Li G, Yang B, Deng X (2014) Roxarsone and its metabolites in chicken manure significantly enhance the uptake of As species by vegetables. Chemosphere 100:57-62. https://doi.org/10.1016/j.chemosphere.2013.12.074

Islam KM, Klein U, Burch DG (2009) The activity and compatibility of the antibiotic tiamulin with other drugs in poultry medicine - a review. Poult Sci 88(11):2353-2359

James S (1980) Thiamine uptake in isolated schizonts of Eimeria tenella and the inhibitory effects of amprolium. Parasitology 80(02):313322

Jeffers TK (1976) Reduction of anticoccidial drug resistance by massive introduction of drug-sensitive coccidia. Avian Dis 20(4):649-653

Jeffers T (1989) Anticoccidial drug resistance: a review with emphasis on the polyether ionophores. Pages 295-308 In: Coccidia and Intestinal Coccidiomorphs. P Yvoré, ed. Proc. 5th International Coccidiosis Conference, Tours, France. INRA, Paris, France

Jeffers TK, Challey JR (1973) Collateral sensitivity to 4hydroxyquinolines in Eimeria acervulina strains resistant to meticlorpindol. J Parasitol 59(4):624-630

Jeffers TK, Tonkinson LV, Callender ME (1988) Anticoccidial efficacy of narasin in battery cage trials. Poult Sci 67(7):1043-1049. https://doi. org/10.3382/ps.0671043

Jenkins M, Klopp S, Ritter D, Miska K, Fetterer R (2010) Comparison of Eimeria species distribution and salinomycin resistance in commercial broiler operations utilizing different coccidiosis control strategies. Avian Dis 54(3):1002-1006. https://doi.org/10.1637/9137111,109-Reg.1

Joachim A, Altreuther G, Bangoura B, Charles S, Daugschies A, Hinney B, Lindsay DS, Mundt HC, Ocak M, S10 S (2018) W A A V P guideline for evaluating the efficacy of anticoccidials in mammals (pigs, dogs, cattle, sheep). Vet Parasitol 253:102-119. https://doi. org/10.1016/j.vetpar.2018.02.029

Jockel J, Wendt B, Loffler M (1998) Structural and functional comparison of agents interfering with dihydroorotate, succinate and NADH oxidation of rat liver mitochondria. Biochem Pharmacol 56(8):10531060 
Jones JE, Solis J, Hughes BL, Castaldo DJ, Toler JE (1990) Production and egg-quality responses of White Leghorn layers to anticoccidial agents. Poult Sci 69(3):378-387

Kadykalo S, Roberts T, Thompson M, Wilson J, Lang M, Espeisse O (2018) The value of anticoccidials for sustainable global poultry production. Int J Antimicrob Agents 51(3):304-310

Kant V, Singh P, Verma PK, Bais I, Parmar MS, Gopal A, Gupta V (2013) Anticoccidial drugs used in the poultry: an overview. Sci Int 1(7): 261-265. https://doi.org/10.17311/sciintl.2013.261.265

Kart A, Bilgili A (2008) Ionophore antibiotics: toxicity, mode of action and neurotoxic aspect of carboxylic ionophores. J Anim Vet Adv 7(6):748-751

Kawazoe U, Chapman HD, Shaw M (1991) Sensitivity of field isolates of Eimeria acervulina to salinomycin, maduramicin, and a mixture of clopidol and methyl benzoquate in the chicken. Avian Pathol 20(3): 439-446

Keeton STN, Navarre CB (2018) Coccidiosis in large and small ruminants. Vet Clin N Am Food Anim Pract 34(1):201-208. https://doi. org/10.1016/j.cvfa.2017.10.009

Kennett RL, Kantor S, Gallo A (1974) Efficacy studies with robenidine, a new type of anticoccidial, in the diet. Poult Sci 53(3):978-986

Keshavarz K, McDougald LR (1981) Influence of anticoccidial drugs on losses of broiler chickens from heat stress and coccidiosis. Poult Sci 60(11):2423-2428

Kinnaird JH, Bumstead JM, Mann DJ, Ryan R, Shirley MW, Shiels BR, Tomley FM (2004) EtCRK2, a cyclin-dependent kinase gene expressed during the sexual and asexual phases of the Eimeria tenella life cycle. Int J Parasitol 34(6):683-692

Klotz C, Marhöfer RJ, Selzer PM, Lucius R, Pogonka T (2005) Eimeria tenella: identification of secretory and surface proteins from expressed sequence tags. Exp Parasitol 111(1):14-23. https://doi. org/10.1016/j.exppara.2005.04.005

Kreiner T, Worliczek HL, Tichy A, Joachim A (2011) Influence of toltrazuril treatment on parasitological parameters and health performance of piglets in the field - an Austrian experience. Vet Parasitol 183(1-2):14-20

Kutuzov MA, Andreeva AV, Voyno-Yasenetskaya TA (2005) Regulation of apoptosis signal-regulating kinase 1 (ASK1) by polyamine levels via protein phosphatase 5. J Biol Chem 280(27):25388-25395

Laczay P (1988) [Compatibility of ionophore antibiotics.] Zur Kompatibilität der ionophoren Antibiotika. Monatshefte für Veterinärmedizin 43(22):786-788

Laczay P, Simon F, Szurop I, Voros G, Lehel J (1988) Study of the compatibility of CH-402 antioxidant with ionophore antibiotics and other chemotherapeutics in broilers. Magyar Allatorvosok Lapja (Hungary)

Laczay P, Simon F, Mora Z, Lehel J (1989) The compatibility of the new ionophore-coccidiostats with other chemotherapeutics in broilers. Dtsch Tierarztl Wochenschr 96(9):449-451

Lebkowska-Wieruszewska BI, Kowalski CJ (2010) Sulfachlorpyrazine residues depletion in turkey edible tissues. J Vet Pharmacol Ther 33(4):389-395. https://doi.org/10.1111/j.1365-2885.2009.01147.x

Leek RG, Fayer R, McLoughlin DK (1976) Effect of monensin on experimental infections of Eimeria ninakohlyakimovae in lambs. Am J Vet Res 37(3):339-341

Lindenthal C, Klinkert MQ (2002) Identification and biochemical characterisation of a protein phosphatase 5 homologue from Plasmodium falciparum. Mol Biochem Parasitol 120(2):257-268

Lindsay DS, Butler JM, Rippey NS, Blagburn BL (1996) Demonstration of synergistic effects of sulfonamides and dihydrofolate reductase/ thymidylate synthase inhibitors against Neospora caninum tachyzoites in cultured cells, and characterization of mutants resistant to pyrimethamine. Am J Vet Res 57(1):68-72

Liu CM, Hermann TE, Downey A, Prosser BL, Schildknecht E, Palleroni NJ, Westley JW, Miller PA (1983) Novel polyether antibiotics X-14868A, B, C, and D produced by a Nocardia. Discovery, fermentation, biological as well as ionophore properties and taxonomy of the producing culture. J Antibiot 36(4):343-350

Logan NB, McKenzie ME, Conway DP, Chappel LR, Hammet NC (1993) Anticoccidial efficacy of semduramicin. 2. Evaluation against field isolates including comparisons with salinomycin, maduramicin, and monensin in battery tests. Poult Sci 72(11): 2058-2063

Maes L, Coussement W, Vanparijs O, Marsboom R (1988) In vivo action of the anticoccidial diclazuril (Clinacox) on the developmental stages of Eimeria tenella: a histological study. J Parasitol 74(6): 931-938

Marhöfer RJ, Mottram JC, Selzer PM (2013) Protein kinases as suitable targets for combating Eimeria spp. protein phosphorylation in parasites. In: Doerig C, Späth G, Wiese M (eds) Protein phosphorylation in parasites. Wiley-VCH Verlag GmbH \& Co. KGaA, pp 317-336. https://doi.org/10.1002/9783527675401.ch15

Maron MI et al (2015) Maduramicin rapidly eliminates malaria parasites and potentiates the gametocytocidal activity of the pyrazoleamide PA21A050. Antimicrob Agents Chemother 60(3):1492-1499. https://doi.org/10.1128/aac.01928-15

Mathis GF, Broussard C (2006) Increased level of Eimeria sensitivity to diclazuril after using a live coccidial vaccine. Avian Dis 50(3):321324. https://doi.org/10.1637/7455-101305r1.1

Matsuoka T, Novilla MN, Thomson TD, Donoho AL (1996) Review of monensin toxicosis in horses. J Equine Vet Sci 16(1):8-15. https:// doi.org/10.1016/S0737-0806(96)80059-1

Mazlum Z, Pradella G (1986) Interactions between narasin and monensin with some antibiotics and chemotherapeutics in broiler chicks. Clin Vet 109:62-63

Mazlum Z, Pickles RW, Pradella G, Pagnani R (1985) Interaction between monensin, narasin or salinomycin and the antibiotics erythromycin, chloramphenicol or tylosin in broiler chicks. Clinica Vet 108: 95-104

McCullough JL, Maren TH (1974) Dihydropteroate synthetase from Plasmodium berghei: isolation, properties, and inhibition by dapsone and sulfadiazine. Mol Pharmacol 10(1):140-145

McDougald LR (1978) Monensin for the prevention of coccidiosis in calves. Am J Vet Res 39(11):1748-1749

McLoughlin DK, Chute MB (1978) Robenidine resistance in Eimeria tenella. J Parasitol 64(5):874-877

Mehlhorn H, Pooch H, Raether W (1983) The action of polyether ionophorous antibiotics (monensin, salinomycin, lasalocid) on developmental stages of Eimeria tenella (Coccidia, Sporozoa) in vivo and in vitro: study by light and electron microscopy. Ztsch Parasitenk 69(4):457-471

Mehlhorn H, Ortmann-Falkenstein G, Haberkorn A (1984) The effects of sym. Triazinones on developmental stages of Eimeria tenella, E. maxima and E. acervulina: a light and electron microscopical study. Ztschr Parasitenk 70(2):173-182

Miner ML, Jensen JB (1976) Decoquinate in the control of experimentally induced coccidiosis of calves. Am J Vet Res 37(9):1043-1045

Mitrovic M, Schildknecht EG (1974) Anticoccidial activity of Lasalocid (X-537A) in chicks. Poult Sci 53(4):1448-1455. https://doi.org/10. 3382/ps.0531448

Miyazaki Y, Shibuya M, Sugawara H, Kawaguchi O, Hirsoe C (1974) Salinomycin, a new polyether antibiotic. J Antibiotics 27(11):814 821

Mollenhauer HH, James Morré D, Rowe LD (1990) Alteration of intracellular traffic by monensin; mechanism, specificity and relationship to toxicity. Biochim Biophys Acta Rev Biomembr 1031(2):225246. https://doi.org/10.1016/0304-4157(90)90008-Z

Müller J, Hemphill A (2016) Drug target identification in protozoan parasites. Expert Opin Drug Discovery 11(8):815-824. https://doi.org/ 10.1080/17460441.2016.1195945 
Mundt HC, Daugschies A, Uebe F, Rinke M (2003a) Efficacy of toltrazuril against artificial infections with Eimeria bovis in calves. Parasitol Res 90(Suppl 3):S166-S167

Mundt HC, Daugschies A, Wüstenberg S, Zimmermann M (2003b) Studies on the efficacy of toltrazuril, diclazuril and sulphadimidine against artificial infections with Isospora suis in piglets. Parasitol Res 90(Suppl 3):S160-S162

Mundt HC, Bangoura B, Mengel H, Keidel J, Daugschies A (2005) Control of clinical coccidiosis of calves due to Eimeria bovis and Eimeria zuernii with toltrazuril under field conditions. Parasitol Res 97(Suppl 1):S134-s142. https://doi.org/10.1007/ s00436-005-1457-9

Mundt HC, Mundt-Wüstenberg S, Daugschies A, Joachim A (2007) Efficacy of various anticoccidials against experimental porcine neonatal isosporosis. Parasitol Res 100(2):401-411

Mundt HC, Dittmar K, Daugschies A, Grzonka E, Bangoura B (2009) Study of the comparative efficacy of toltrazuril and diclazuril against ovine coccidiosis in housed lambs. Parasitol Res 105(Suppl 1): S141-S150. https://doi.org/10.1007/s00436-009-1505-y

Nachman KE, Baron PA, Raber G, Francesconi KA, Navas-Acien A, Love DC (2013) Roxarsone, inorganic arsenic, and other arsenic species in chicken: a U.S.-based market basket sample. Environ Health Perspect 121(7):818-824. https://doi.org/10.1289/ehp. 1206245

Nagi MS, Mathey WJ (1972) Interaction of Escherichia coli and Eimeria brunetti in chickens. Avian Dis 16(4):864-873

Naujokat C, Fuchs D, Opelz G (2010) Salinomycin in cancer: a new mission for an old agent. Mol Med Rep 3(4):555-559. https://doi. org/10.3892/mmr_00000296

Norcross MA, Siegmund OH, Fraser CM (1974) Amprolium for coccidiosis in cattle: a review of efficacy and safety. Vet Med Small Anim Clin 69(4):459 passim

Odden A et al (2018) Controlled efficacy trial confirming toltrazuril resistance in a field isolate of ovine Eimeria spp. Parasit Vectors 11(1): 394. https://doi.org/10.1186/s13071-018-2976-4

Oehme FW, Pickrell JA (1999) An analysis of the chronic oral toxicity of polyether ionophore antibiotics in animals. Vet Hum Toxicol 41(4): 251-257

Peek HW, Landman WJ (2006) Higher incidence of Eimeria spp. field isolates sensitive for diclazuril and monensin associated with the use of live coccidiosis vaccination with paracox-5 in broiler farms. Avian Dis 50(3):434 439. https://doi.org/10.1637/7486-121205r.1

Peek HW, Landman WJM (2011) Coccidiosis in poultry: anticoccidial products, vaccines and other prevention strategies. Vet Q 31(3):143161. https://doi.org/10.1080/01652176.2011.605247

Perelman B, Abarbanel JM, Gur-Lavie A, Meller Y, Elad T (1986) Clinical and pathological changes caused by the interaction of lasalocid and chloramphenicol in broiler chickens. Avian Pathol 15(2):279-288. https://doi.org/10.1080/03079458608436288

Pines M, Vlodavsky I, Nagler A, Gurwitz D (2000) Halofuginone: from veterinary use to human therapy. Drug Dev Res 50(3-4):371-378. https://doi.org/10.1002/1098-2299(200,007/08)50:3/43.0.CO;2-R

Reid WM (1975) Progress in the control of coccidiosis with anticoccidials and planned immunization. Am J Vet Res 36(4 Pt 2):593-596

Reid AJ et al (2014) Genomic analysis of the causative agents of coccidiosis in domestic chickens. Genome Res 24(10):1676-1685. https:// doi.org/10.1101/gr.168955.113

Ricketts AP, Glazer EA, Migaki TT, Olson JA (1992) Anticoccidial efficacy of semduramicin in battery studies with laboratory isolates of coccidia. Poult Sci 71(1):98-103. https://doi.org/10.3382/ps. 0710098

Riddell FG (2002) Structure, conformation, and mechanism in the membrane transport of alkali metal ions by ionophoric antibiotics. Chirality 14(2-3):121-125. https://doi.org/10.1002/chir.10052
Ruiz A et al (2012) Control strategies using diclazuril against coccidiosis in goat kids. Parasitol Res 110(6):2131-2136. https://doi.org/10. 1007/s00436-011-2746-0

Rychen $\mathrm{G}$ et al (2018) Safety and efficacy of COXAM® (amprolium hydrochloride) for chickens for fattening and chickens reared for laying. EFSA J 16(7):e05338. https://doi.org/10.2903/j.efsa.2018. 5338

Ryley JF (1975) Lerbek, a synergistic mixture of methyl benzoquate and clopidol for the prevention of chicken coccidiosis. Parasitology 70(Part 3):377-384

Ryley JF, Betts MJ (1973) Chemotherapy of chicken coccidiosis. Adv Pharmacol Chemother 11:221-293

Rypula K, Porowski M, Kaba J, Gorczykowski M, Deniz A (2012) Effect of isosporiasis prevention with toltrazuril on long-term pig performance. Sci World J 2012:486324. https://doi.org/10.1100/2012/ 486324

Scala A, Demontis F, Varcasia A, Pipia AP, Poglayen G, Ferrari N, Genchi M (2009) Toltrazuril and sulphonamide treatment against naturally Isospora suis infected suckling piglets, is there an actual profit? Vet Parasitol 163:362-365

Schuhmacher A et al (2006) Tiamulin and semduramicin: effects of simultaneous administration on performance and health of growing broiler chickens. Poult Sci 85(3):441-445. https://doi.org/10.1093/ ps/85.3.441

Scribner A et al (2009) Synthesis and biological activity of anticoccidial agents: 2,3-diarylindoles. Bioorg Med Chem Lett 19(5):1517-1521. https://doi.org/10.1016/j.bmcl.2009.01.001

Segev G, Baneth G, Levitin B, Shlosberg A, Aroch I (2004) Accidental poisoning of 17 dogs with lasalocid. Vet Rec 155(6):174-176

Sharma N, Bhalla A, Varma S, Jain S, Singh S (2005) Toxicity of maduramicin. Emerg Med J 22(12):880-882. https://doi.org/10. 1136/emj.2004.020883

Shirley MW, Smith AL, Blake DP (2007) Challenges in the successful control of the avian coccidia. Vaccine 26;25(30):5540-7. https://doi. org/10.1016/j.vaccine.2006.12.030

Shirley MW, McDonald V, Bellatti MA (1986) Eimeria brunetti: selection and characteristics of a precocious (and attenuated) line. Avian Pathol 15(4):705-17. https://doi.org/10.1080/03079458608436333

Shlosberg A, Perl S, Harmelin A, Hanji V, Bellaiche M, Bogin E, Cohen R, Markusfeld-Nir O, Shpigel N, Eisenberg Z, Furman M, Brosh A, Holzer Z, Aharoni Y (1997) Acute maduramicin toxicity in calves. Vet Rec 140(25):643-646

Shrestha A, Freudenschuss B, Jansen R, Hinney B, Ruttkowski B, Joachim A (2017a) Experimentally confirmed toltrazuril resistance in a field isolate of Cystoisospora suis. Parasit Vectors 10(1):317

Shrestha A, Palmieri N, Abd-Elfattah A, Ruttkowski B, Pages M, Joachim A (2017b) Cloning, expression and molecular characterization of a Cystoisospora suis specific uncharacterized merozoite protein. Parasit Vectors 10(1):68. https://doi.org/10.1186/s13071-017-2003-1

Shumard RF (1957) Ovine coccidiosis; incidence, possible endotoxin, and treatment. J Am Vet Med Assoc 131(12):559-561

Smith CK, Galloway RB (1983) Influence of monensin on cation influx and glycolysis of Eimeria tenella sporozoites in vitro. J Parasitol 69(4):666-670

Smith C II, Strout R (1980) Eimeria tenella: effect of narasin, a polyether antibiotic on the ultrastructure of intracellular sporozoites. Exp Parasitol 50(3):426-436

Smith CK, Galloway RB, White SL (1981) Effect of ionophores on survival, penetration, and development of Eimeria tenella sporozoites in vitro. J Parasitol 67(4):511-516

Stephan B, Rommel M, Daugschies A, Haberkorn A (1997) Studies of resistance to anticoccidials in Eimeria field isolates and pure Eimeria strains. Vet Parasitol 69(1):19-29

Talmon P, Jager LP, de Leeuw WA, Timmer WJ (1989) Coccidiosis in lambs: observations in the preventive use of an amproliumcontaining medicated feed. Tijdschr Diergeneeskd 114(11):611-617 
Tang KL, Caffrey NP, Nóbrega DB, Cork SC, Ronksley PE, Barkema HW, Polachek AJ, Ganshorn H, Sharma N, Kellner JD, Ghali WA (2017) Restricting the use of antibiotics in food-producing animals and its associations with antibiotic resistance in food-producing animals and human beings: a systematic review and meta-analysis. Lancet Planet Health 1(8):e316-e327. https://doi.org/10.1016/ S2542-5196(17)30141-9

Taylor MA, Catchpole J (1994) Review article: coccidiosis of domestic ruminants. Appl Parasitol 35(2):73-86

Tynan EJ 3rd, Nelson TH, Davies RA, Wernau WC (1992) The production of semduramicin by direct fermentation. J Antibiot (Tokyo) 45(5):813-815

Umemura T, Nakamura H, Goryo M, Itakura C (1984a) Histopathology of monensin-tiamulin myopathy in broiler chicks. Avian Pathol 13(3):459-467. https://doi.org/10.1080/03079458408418547

Umemura T, Nakamura H, Goryo M, Itakura C (1984b) Ultrastructural changes of monensin-oleandomycin myopathy in broiler chicks. Avian Pathol 13(4):743-751. https://doi.org/10.1080/ 03079458408418571

Verheyen A, Maes L, Coussement W, Vanparijs O, Lauwers F, Vlaminckx E, Borgers M, Marsboom R (1988) In vivo action of the anticoccidial diclazuril (Clinacox) on the developmental stages of Eimeria tenella: an ultrastructural evaluation. J Parasitol 74(6):939-949

Verheyen A, Maes L, Coussement W, Vanparijs O, Lauwers F, Vlaminckx E, Marsboom R (1989) Ultrastructural evaluation of the effects of diclazuril on the endogenous stages of Eimeria maxima and E. brunetti in experimentally inoculated chickens. Parasitol Res 75(8):604-610

von Samson-Himmelstjerna G et al (2006) Clinical and epidemiological characteristics of Eimeria infections in first-year grazing cattle. Vet Parasitol 136(3-4):215-221. https://doi.org/10.1016/j.vetpar.2005. 11.022

Wang CC (1975) Studies of the mitochondria from Eimeria tenella and inhibition of the electron transport by quinolone coccidiostats. Biochim Biophys Acta 396(2):210-219

Wang CC (1976) Inhibition of the respiration of Eimeria tenella by quinolone coccidiostats. Biochem Pharmacol 25(3):343-349

Wang CC (1978) Biochemical and nutritional aspects of coccidia. Avian Coccidiosis, pp 135-184

Wang CC (1982) Biochemistry and physiology of coccidia. p167-228 in: The biology of the coccidia. P.L. Long. University Park Press, Baltimore
Wang Z, Suo X, Xia X, Shen J (2006) Influence of monensin on cation influx and $\mathrm{Na}^{+}-\mathrm{K}^{+}$-ATPase activity of Eimeria tenella sporozoites in vitro. J Parasitol 92(5):1092-1096. https://doi.org/10.1645/ge-783r.1

WHO (2017) WHO guidelines on use of medically important antimicrobials in food-producing animals. ISBN: 978-92-4-155,013-0. https://www.who.int/foodsafety/publications/cia_guidelines/en/

Williams RB (1997) The mode of action of anticoccidial quinolones (6decyloxy-4-hydroxyquinoline-3-carboxylates) in chickens. Int $\mathbf{J}$ Parasitol 27(1):101-111

Williams RB (1999) A compartmentalised model for the estimation of the cost of coccidiosis to the world's chicken production industry. Int $\mathrm{J}$ Parasitol 29(8):1209-1229. https://doi.org/10.1016/S00207519(99)00086-7

Williams RB (2006) Tracing the emergence of drug-resistance in coccidia (Eimeria spp.) of commercial broiler flocks medicated with decoquinate for the first time in the United Kingdom. Vet Parasitol 135(1):1-14

Wong DT, Horng JS, Wilkinson JR (1972) Robenzidene, an inhibitor of oxidative phosphorylation. Biochem Biophys Res Commun 46(2): 621-627

Yoder CA, Graham JK, Miller LA (2006) Molecular effects of nicarbazin on avian reproduction. Poult Sci 85(7):1285-1293. https://doi.org/ $10.1093 / \mathrm{ps} / 85.7 .1285$

Zaionts VI, Krylov MV, Loskot VI, Kirillov AI (1978) Biosynthesis of folic acid in Eimeria tenella (Coccidia). Parazitologiia 12(1):3-8

Zhang DF et al (2012) Anticoccidial effect of halofuginone hydrobromide against Eimeria tenella with associated histology. Parasitol Res 111(2):695-701

Zhou BH, Wang HW, Wang XY, Zhang LF, Zhang KY, Xue FQ (2010) Eimeria tenella: effects of diclazuril treatment on microneme genes expression in second-generation merozoites and pathological changes of caeca in parasitized chickens. Exp Parasitol 125(3):264-270

Zhou BH, Wang HW, Zhao ZS, Liu M, Yan WC, Zhao J, Zhang Z, Xue FQ (2013) A novel serine/threonine protein phosphatase type 5 from second-generation merozoite of Eimeria tenella is associated with diclazuril-induced apoptosis. Parasitol Res 112(4):1771-1780

Publisher's Note Springer Nature remains neutral with regard to jurisdictional claims in published maps and institutional affiliations. 